\title{
The Effects of Border Porosity on Nigeria's National Security: A Study of Nigeria's Northeastern Border to Cameroon
}

\author{
Abdulkarim Abdullahi and Yesmin Abubakar Gawi \\ Nile University of Nigeria, Abuja, Nigeria
}

\begin{abstract}
The issue of border porosity is something that scholars of international relations, contemporary studies, international communities, and international law are focusing on. This is because all the countries in the world within their territory share their boundaries with one or two countries. This also does not change in the case of Africa, rather, Africa's borders are those that are demarcated without considering that maintaining their porosity is difficult. This is as a result of the balkanization of Africa into smaller nations by the Europeans, where they did not consider the interrelationship between the neighbouring countries; the shared culture, and values that have been in existence before the European's invasion into Africa, where it has been practiced in a single form. This paper studied the effect of border porosity on Nigeria's national security: A study of Nigeria's northeastern border to Cameroon. In doing that, the paper aimed at examining the effect of border porosity on Nigeria's national security. Adopting a qualitative approach to study, this paper adopted a secondary method of gathering data; where data was gathered from textbooks, journals, articles, published and unpublished works, and the internet. In conducting this research, the securitization theory was adopted to explain why states have to deal with issues that constitute national security threats and challenges. The major finding of this paper is that; border porosity led to food scarcity in the northeast, which in the struggle for food people get into serious crises. Also, the level of kidnapping and insecurity has increased in that region.
\end{abstract}

Keywords: Border porosity, migration, Boko-haram, national security, communal value, insecurity

\section{INTRODUCTION}

$\mathrm{C}$ ountries in Africa today are facing the serious challenge of managing their borders to the extent that their territorial sovereignty is in danger. This is because interdependence between states today has become something inevitable and beyond individual state's control, as Aristotle stated "no country is an island of its own", therefore, states need one another to survive and conduct a relationship with one another. All matters in their relations are to protect and promote their national interests by displaying their domestic politics at the international level. Among the national interests' border protection happened to be the most important factor because among the qualities of the state; it is permanent territory. So, therefore, borders happened to be a strong component that the state has to protect. Though with the pressure from the African countries to manage and control border management systems, cross-border trading is still in increase, where citizens move from the country of their origin to search for greener pastures elsewhere.Babatola, (2015, p. 3 ), in his writing, gave the estimate of the entire borders that Nigeria shares in West Africa, though, this project mainly focuses on the border with the central African country; Cameroon.According to Babatola, Nigeria is placed (1497 $\mathrm{km})$ to Niger, to Chad $(87 \mathrm{~km})$, and Cameroon $(1690 \mathrm{~km})$, and has a "coastline of at least $853 \mathrm{~km}$. Nigeria's claim to territorial sea (offshore space) rose from 3 miles of the continental shelf and about 200 miles on exclusive fishing zones from 1958 to 1978 as a country signatory to conventions on the continental shelf despite its inability to determine its extent of the claim."

States in international relations out of their interests try to protect both their citizens and the territory from international aggression but because of today's state interdependence and globalization, and migration it is often difficult to fully control border porosity or to stop it in general, but can be minimally controlled. This is because globalization today has made the state borders weak with the name of development and civilization, and not only globalization migration also is among the factors that bring about border porosity.Another factor that makes it difficult to control border porosity is how States share their borders. In Africa for example, countries share borders to the extent that some are only water springs or hills that separate one country from another. In-country ' $A$ ' you will see a family with relatives in-country ' $B$ ' and this follows how the then colonial masters disintegrated Africa among themselves during the colonial period, and while giving independence to the African states, Africa as a continent world Balkanized into smaller and many sovereign countries which their borders are interconnectedness. Okumu (2011, p. 1), in his writing, stated some realities about the African border system. "These realities give urgency to African countries to put in place effective border management systems that minimize border tensions, increases joint enforcement and surveillance efforts, decreases organized crime activities by syndicates and traffickers in borderlands, generate a common understanding of border insecurities and approaches to addressing them, secures the flow of goods and people in the spirit of regional and continental integration, 
integrates and develops marginalized border areas through provision of essential infrastructure and promotion of a sense of security and well-being among the border population, enhances communication and information exchange between neighboring countries, maintains borders in ways that do not obstruct cross-border trading and legal movements of people, harmonizes, and enables borders to be sources of mutual trust and harmony between neighbors."

So, this makes it difficult with this nature for African states to control borders, for example from the North-Eastern part of Nigeria where Cameroon shares a border with Nigeria, a state (Adamawa state) from history the state was forced to join Nigeria and leave part of Cameroon, and for that the state shares almost same religion culture and belief with northern Cameroon. As of today, every Friday Cameroon citizens enter Adamawa state for market purposes also Nigerian citizens enter Cameroon for the same purpose. So, this makes the Nigerian border with Cameroon become porous and difficult to control, and this system of economic purpose fails in giving Nigeria security particularly the Threat of Boko Haram kidnapping among other threats. This project is to examine the effect of border porosity on Nigerian national Security, taking the border of the North-Eastern part of Nigeria and Cameroon as a study. Looking at the concept of border porosity it is defined in a general term as the leakage or break of the border that allows the illegal and unofficial migration of people goods and ammunitions from one country to another.

Adopting a qualitative approach to write this paper, the paper aimedto examine the effect of border porosity on Nigeria's national security. The research paper asked the question of whether Nigeria is having a good border management system that controls border porosity. Securitization theory international relations was adopted in writing this research to show how states treat any international threat to national security. This paper is categorized into three sections. The first section discussed the introduction, the application of theory to the research paper, and the basic definitions of concepts. The second section discussed migration and Nigerian borders, and Nigeria and the African border history. The last section discussed the effect of border porosity on Nigeria's national security, then the conclusion and recommendation if any.

\section{THEORETICAL FRAMEWORK}

\subsection{Securitization theory}

Securitization theory is a theory of international relations that shows how politicians and decision-makers design national security policy. This theory was developed by the Copenhagen School of Barry Buzan in the 1990s because most writings emerged at the conflict and Peace Research Institute in the 1990s. In her writing, Eroukhmanoff (2018), that according to this theory political issues constitute highly security issues that should be dealt with urgently, and when neglected, it will be dangerous, threatening, menacing, alarming among other harmful factors to the actor who is having the institutional and social power to move the issue beyond politics. Taking immigration as an example, a threat to national security moved immigration from a low priority of political concern to a high priority that requires strong action; such as securing borders. This theory challenges the traditional theory of security in the sense that by referring to an issue as security, then it has become a security problem. Securitization theory has the following basic assumptions. They include:

1. The end of the cold war had widened over the ideas of security to include not military and political aspects of the threat. That this expanded security included; regional security, human security, together with ideas of culture and identity.

2. That feminism is having an important role to play in the production of security, and that gender and security were intertwined.

3. That theory determined the societal, military, economic, environmental, and political sectors of a country.

This theory is adopted for this research project because border porosity is regional security that affects both economic and political stability in Nigeria. Besides, border porosity is considered a national policy this is because of protecting Nigeria's integrity, and the flows of illegal migrants' cause a national threat to Nigeria's security.

\section{BASIC CONCEPTUAL DEFINITIONS}

\subsection{The concept of border porosity}

Marking the end of ideological war between the two power blocs, international relations took a new dimension, involving the phenomenon of border porous, and crimes recurring associated with it. This angled a serious threat to international peace and security. This emergence of border porosity expanded more especially with the emergence of globalization (Simon, 2011). The emergence of globalization encouraged the opening of borders of countries of the world, and thus, countries have a different political, cultural, and socioeconomic sphere that emerged together to form regional arrangements and other transnational activities. The history of border porosity in Africa can be traced back to the time of the colonial administration, and the second administration that is; during the political independence of African countries. Before the independence of African countries, Africa was more of establishing a sphere of influence for political and economic purpose than the creation of boundary, but colonial administration demarcated the boundaries with no respect to socio-cultural basic of African people, and no explanations why African people were scattered across borders (Akinyemi, 2013, p. 43).

When speaking of borders, they are territories of states in which states exercise full and legal jurisdictions; the aspect that marks the legal restriction of one country's territory or political unit and that of one another. To Ikome (2012), that 
border is a tool that illuminates the patterns and nature of domestic and international different ways of interactions. In their writing, Gerstein et al (2018), defines national borders as geographical boundaries of a state, where the government of that state exercise full legal jurisdiction over the actions, structures, and people residing within the boundaries. To them, the concept of border is often associated with the establishment of boundary control and in some cases to prevent the flow of people, goods, and services by establishing a security perimeter for controlling entry into the territory of an independent country.

Marenin (2010, p. 34), identified several types of borders. He mentioned that not all borders are alike, and they are being managed in different ways. The areas, the space, the nature, threats that have to be controlled, and the types of equipment needed and the skills to use them, the personnel required to make the borders differ from one country to another.

\subsection{The concept of national security}

Security, as a basic concept, is usually related to reducing value threats, especially reducing the survival of individuals, groups, or objects in a short period. However, Adebakin (Adebakin, 2012, p. 8) defines security as an activity that guarantees the protection of the country. People and public property are protected from future threats, hazards, frustrations, and all other forms of danger. Safety refers to the prevention of hidden dangers and harmful interference in the daily life of the home, office, or community. Security should be connected with peace, security, happiness, and the protection of human and material resources or the absence of crises. "Security is seen as any mechanism specifically designed to mitigate the most serious and direct threats that prevent people from pursuing their most precious value. The fundamental aspect of social survival is its law-and-order security based on national laws: economic, environmental, and demographic issues because They are important for understanding the new causes of family conflicts.Other threats to national security are pollution, poverty, crime, and underdevelopment, which exacerbate conflicts. Such as hunger, disease, and oppression, and protect them from sudden and harmful disturbances in daily life at home, at work, or in the community. "National security can be summarized as "prevention of disease, hunger, unemployment, crime, social conflict, political oppression, and environmental threats."The national security of a country covers other important areas, such as environmental protection, social and food security, especially the promotion of internal peace. If there is no adequate protection of life and property, the system will fall into anarchy, chaos, and even eventually disintegrate. It can be military, economic, ideological, or cultural. People not only need to protect themselves from outside attacks but also the devastating consequences of civil strife, unemployment, hunger, hunger, disease, ignorance, homelessness, environmental degradation, and social pollution. -Economic injustice. Security is essential to national reunification, peace, and sustainable development.
Therefore, it is obvious that national security is an ideal and indispensable requirement for a country's economic growth and development. Urhi (2014) explained that security issues have been at the center of the development debate for decades. Since the end of the Cold War, made by various scientists redefining the concept of security At the center of the security debate, people are trying to deepen and extend the concept of security from the national level to society and individuals, and from military to non-military. This concept is usually related to reducing the threat to value, especially to the survival of individuals, groups, or objects in a short period. Security is an activity that protects the country, people, and community property from future threats, dangers, incidents, and all other forms of danger. "National security" is seen as the physical protection and protection of citizens and our territorial integrity, and contributes to the economic well-being and prosperity of Nigerians in a safe environment that promotes our national interests and the interests of our foreign partners. In addition, safety refers to the prevention of hidden dangers and harmful interference in daily life in the home, office, or community. Evetan and Urhi believe that security should especially be linked to peace, safety, happiness, and protection of human and material resources, or to eliminate the threat of personal injury.Consider mechanisms specifically designed to mitigate the most serious and immediate threats that will prevent people from pursuing their valuable value. Without adequate protection of life and property, the system will live in anarchy, violence, chaos, and possible disintegration. It can be military, economic, and ideological. People not only need to be protected from external attacks, but also internal shocks, unemployment, hunger, hunger, disease, ignorance, homelessness, environmental degradation and pollution, and the destructive effects of social and economic injustice.Daniel and Kwopman believe that security is essential to national unity, peace, and sustainable development

\section{NIGERIA AND THE AFRICAN BORDERS}

When discussing international boundaries, we should put in mind that are such walls and partitions that separate people on opposite sites. Though, states' boundaries are manmade, which identifies that the territory separated belongs to one state, and other separated territory belongs to another. Countries since their political independence are being drafted and designed with their territory as part of their independence; based on the qualities of independence state recognized by international law and the international community that state as an independent body must have an uninterrupted and nonintervening territory. This then in international relations pushes states to start protecting their borders from external intervention, and make it to be the most important part of their national interests; that is, protecting the state from any form of aggression to maintain its sovereignty.

The situation also remains the same in Africa. African countries in the middle of the late 90 s started gaining their political independence from the colonial masters; this is where African states were divided into many states where borders 
are being shared so tightly and left with many issues to be tackled by Africans themselves. Africa as a continent has boundaries of 109 internationally, and less than $25 \%$ of the boundaries are demarcated, so, this creates room for much border porosity. Across these 109 borders, only 414 roads in total linking the African states, where out of these roads, 69 are with no customs on the roads (Okumu, 2011, p. 4). These borders are shared with Nigeria, and many of these borders are porous, because of either lack of roads linking the countries or because of poor mismanagement of the borders by the states bordering Nigeria and Nigeria herself.Nigeria because of its largest size geographically, shares large borders with its neighboring African states, particularly to the West African region. Nigeria from Benin republic, shares (773) kilometers, from her border with the Niger Republic, which shares (1497) kilometers, from the Chad border it shares (87) kilometers, and from Cameroon border it shares (1690) kilometers (Babatola, 2015, p. 3).

\subsection{Migration and Nigerian borders}

Migration can have a scope of social, social, political, and monetary impacts. It includes the exchange of expertise and abilities, money-related resources (counting settlements), and the exchange of individuals starting with one area then onto the next. Movement additionally has ramifications for the individual, the zone of the source, and the region of objective on the family, family unit, society, the economy, and advancement all in all. The impact of worldwide relocation isn't restricted to settlements and money inflows alone. It incorporates a wide scope of advancement issues administration, what's more, lawful assurance, business and social, security, wellbeing administrations and training, tertiary instruction, information, and aptitudes advancement, financial development, money-related administrations and development, agribusiness, and provincial infrastructural advancement, and natural issues. All these go under migration and human turn of events, characterized by the United Nations Development Programme (UNDP) as a cycle of amplifying individuals' decisions, which involves two significant things, in particular, extending human abilities and working (International Organization for Migration, 2014, p. 4).

Nigeria is among her policy of Afro-centric, consider her neighbours to be her brother always. Nigeria occupied a vast geographical area, and a mass population than the countries in the West African region, also including the countries of Francophone origins in terms of diversity, socio-cultural power, and numerical strength. Adepoju (2005) is of the view that because of high population pressure, poor economic performance poverty, and endemic conflicts West Africa has experienced a series of migrations. Before the period of colonization, we have seen how people in West Africa migrate in search of new land for safe settlement and fertile farming, security, and shelter. With the coming of colonial masters, during this time different factors led to the migration and population movements, cross-border movements that even give rise to male domination in society. The factors may include; political and economic structures, imposing a tax on people, and territorial boundaries among others (Adepoju, 2005). In his writing, Amin (1974), is of view that during the colonial period, what led to high migration was the result of provoked large-scale labour, plantations, mines, economic measures including compulsory retirements, contract and agreements that support cheap labour, and public administration that is beyond local supply.

Nigeria sharing borders with African neighbours of different cultures, for example, from the east it shares a border with Cameroon, from the western part there is Benin republic, and to the northeast there is Chad, and some parts of Cameroon, to the West there is Niger republic. All people of these countries are of African descent, and maintain agriculture as a source of income. Though Nigeria and Cameroon had discovered other sources, Nigeria remains the most industrialized among the mentioned states, and because of that reason, migration for a good standard of living increases (Adeola \&Oluyemi, 2012, p. 5). In West Africa, migration has been part of the most dynamic feature because most ethnic groups of each country settle in more than one country in the area. The artificial borders created by the Europeans made the migration to become a serious factor among the African countries. This is because before colonial time, almost all Africans live together, and even today because of the closeness, there are inter-marriages in far remote areas (Mabogunje, 1972). Some factors made international migration between Nigeria and her neighbors easy. According to Stoffer (1946), these factors include; the short distance and the porosity of the borders, no language barriers between the people living in local communities in Nigeria and the neighbouring countries, also, the harsh weather conditions in places like Niger, Cameroon, and Chad made Nigeria be the ideal destination of their migration. Migration between Nigeria and her neighbouring countries because of lack of state intervention became a serious matter and continues to be creating and expanding dangerous impacts on national security and an increase in criminal activities in Nigeria because of the porosity of the border (Adeola \&Oluyemi, 2012).

\subsection{The effect of Nigeria-Cameroon border porosity on Nigerian national security}

The porousness of the Nigerian borders led to the following challenges to Nigerian national security. They include the following:

\section{ECONOMIC BACKWARDNESS}

Nigeria has struggled since its sovereignty to date with growth problems. The country's recent growth rate places it among the top countries in the world for a "developing" population. Furthermore, Nigeria has low GDP per capita, massive unemployment, a poor economy of human capital depreciation, low investment, and other problems that the nation's entire population needs to be created. Civilian administrations have, however, have made tremendous strides to revitalize the economy and boost human resources since 
1999. in the face of strong political resistance and terrorism threats, progress in Airport re-modeling, universities repositioning, new construction, and new highways as well as the creation of jobs, as well as improved public transportation is being made in the world. While attacks carried out by Boko Haram have aided Nigeria's progress, in a manner of speaking, on the contrary, the movements of the Boko Haram have been an obstruction to Nigeria's growth (Awortu, 2015, p. 216). In the writing of Muhammad, (2017), many economic issues were recorded because of the border porosity. The economic issues included:

i. Trade Barriers in Nigeria: According to one study forum, it reveals that a lot of Nigerian firms do not have a market climate. The key and widely listed groups of trade barriers include inefficiency and imperviousness in border management and the lack of transport infrastructure. Other issues include market entry barriers such as import prohibitions, provision of local content, and import and export licensing rules that offer protection against poorer quality imports for native producers. There are many problems in the general market environment. A weak security environment (the availability and answering times of the police and the preparation and capacity to prosecute illegal acts) has made the maintenance of precautionary goods and valuable assets very difficult, particularly the ex-pats. Delays at Nigerian ports are thus exacerbated by inefficient control of borders and are a result of total maladministration, immature transport arrangements, and corruption. Businessmen consistently condemn the way so many government agencies are treated. Other authorities of the administration, inadequate port clearing personnel, and unfortunate facilities charge Unreasonable charges (Kathleen, 2014).

ii. Optimization of Border administration Process: In 2013, the federal government in Nigeria launched a website to provide importers and exporters with statistics. The next step is to facilitate the real process of clearing, including the incorporation of other government departments and the private sector through the portal. This should start with products with the lengthiest delays, followed by other forms of strategic products. Secondly, for each applicable government department, specific procedure guidelines and a complete list of appropriate permits should be created for each product form. The single portal of the window should allow importers to register, upload paperwork, payment and monitor the whole process online. The number of workers operating in ports can be minimized. Thirdly, a port with access restricted to registered clearing agents approved clearing agents or persons or members of a business with goods verified in the port should be protected. Fourth, federal departments can immediately change and preserve digital documents, so that redundant search procedures can be recovered and removed easily. Additional regulatory authorities, deficient port clearing workers, and unfortunate installations fee Excessive burden.

\subsection{Food Security:}

It can be deduced from the above that Nigeria is not immune to the problems of food security. Of course, about $70 \%$ of the people of Nigeria survive on N100 a day and have a firmly established system of violence, poverty, and hunger. Nigeria remains a rural economy, despite its position as an oildependent country. This sector generates more than $40 \%$ of the GDP with 60 to $70 \%$ of the population participating in agriculture productively. However, there are major subnational variations. In the southeast, for example, $22 \%$ of residents live in rural areas, most of which are involved in non-agricultural practices (Akinsanmi, 2005).Food safety is often characterized as a state in which everyone has at all times access to enough, secure and nutritive food to satisfy their diverting needs and desires for an active and healthy life both physically and economically (World Food Summit, 2003). Food protection is the capacity of countries, regions, or households to achieve annual food intake goals. The Committee on World Food Security has also argued that food security involves access to enough food for all household members physically and economically without an unnecessary chance of losing access. Also describing food security as a condition where everyone at all times has access to safe and nutritious food to sustain a good and prosperous existence, was the Food and Farm Organization (FAO) (2008). This includes usability, affordability, and correct use. Security of food means ensuring that enough food is made available; preserving adequate supply at reasonably secure levels employing domestic production; enabling access to food for those who require it, and ensuring the biological use of food. This assumes that the spoilage, disease, and nutritional balance are properly preserved. The World Bank (2007) has looked at food safety as a means of access to adequate food for active and stable living for all populations at all times. Therefore, food safety is people-based and means that all households are not at risk of losing sufficient food, whether physically or economically.

Food security is often characterized as a state in which everyone has at all times access to enough, secure and nutritive food to satisfy their diverting needs and desires for an active and healthy life both physically and economically (World Food Summit, 2003). Food protection is the capacity of countries, regions, or households to achieve annual food intake goals. The Committee on World Food Security has also argued that food security involves access to enough food for all household members physically and economically without an unnecessary chance of losing access. Also describing food security as a condition where everyone at all times has access to safe and nutritious food in order to sustain a good and prosperous existence, was the Food and Farm Organization (FAO) (2008). This includes usability, affordability, and correct use. Security of food means ensuring that enough food is made available; preserving adequate supply at reasonably 
secure levels by means of domestic production; enabling access to food for those who require it and ensuring the biological use of food. This assumes that the spoilage, disease, and nutritional balance are properly preserved. The World Bank (2007) has looked at food safety as a means of access to adequate food for active and stable living for all populations at all times. Therefore, food safety is people-based and means that all households are not at risk of losing sufficient food, whether physically or economically. As a result of an increase in population in the northeastern part of Nigeria that sharesa border with Cameroon, the food produced in the region is not enough for the people of that region to feed on. So, that creates a huge challenge because of the border porous, and lack of a good border management system.

\subsection{Kidnapping and human trafficking}

Humans are not new to trafficking. It is an ancient practice that has changed overtime from bondage to its current state. Before it was criminalized in 2000 under the United Nations Protocol to Prevent, Suppress and Punish Trafficking in Persons, including Women and Children, known as the Palermo Protocol, the scourge noticed that the international community was being criminalized. Since then, concerns of trafficking in persons among researchers and professionals have gained traction largely because of the increased political understanding of the threats and the deaths of victims incurred by the violence. However, research has shown that the problems are little understood in the African context and cause other causes to be questioned beyond the prescriptive push-pull factors. Nigeria's porous frontier with its northern neighbor, Niger, was used as slaves by smugglers who smuggle young girls into Europe.

Nigeria is also the wealthiest and most populated in West Africa and Nigeria dwarfs all of these countries in terms of fiscal, demographic, and military ability. This explains the reasons why crises like political unrest, drought, and diseased conditions in neighboring countries break over Nigeria because their neighbors rely exclusively on Nigeria. The former President of Nigeria also demonstrated this in Babangida's address, saying that no one is willing to profit from any subregion's economic failure. This means Nigeria's national safety as illustrated in both the breadth and scale of cross-border smuggling operations, which are achieved in its everyday contact, represents the safety and security of its immediate neighbors. Ghana, however, was experiencing an economic crisis in which many Ghana people flew to Nigeria to reach their ends. It affected Nigeria seriously, because these illegal aliens infiltrated the region, that she had to send them back to her homeland. Besides, the above considerations aim to threaten the country by extending life and property to internal instability and informing cross-border activities one way or another. Moreover, convergence and co-operation are essential during the 21 st century which is marked by globalization, until the current global order loses us out. The challenges get more difficult and demand a new solution as globalization develops. In these circumstances we cannot rest on our quest for peace on our Nigerian national boundaries, or else the world remains hostile and insecure to the citizens of Nigeria (Adesola, 2008).

In the writing of Akinyemi (2013), it had reported having said that:

The irony is that the boundaries of western Africa are not sufficiently protected by the military. The smugglers live across the border and are familiar with routes more than attached military forces who are solely responsible for managing the frontier, according to respondents in the Nigerian customs office. It is no wonder that migration can be accomplished since the influx of people and goods in the country is minimal to no hindrance. This in turn allows people to travel quickly and indiscriminately into neighboring countries. The boundary porosity has also strengthened unlawful commercial interactions such as the trade of human beings, drug trafficking, and many others. Nigeria respondents argued that their motion was made possible by the porous existence of the western African frontier. Some of those who have been affected across the Nigerian borders with the intention to cross Nigeria, Libya, and later Europe, and do not have the requisite travel documents. The porosity of the African frontiers seems to be encouraging continuous action of human trafficking, as well as lack of adequate protection and identification structures. Nigeria has unused, unreached, unused, or without a functioning Government presence as the largest country in West Africa. The high poverty levels in the neighboring countries are also compounding this. Nigeria is now a hot spot of trade of human beings, where smugglers benefit from the absence of successful monitoring, safety, and identification schemes. Visas are obtained by fraudulent means or by forgery, often in conjunction with agents of immigration. In addition, the smugglers, several secret recruiting sites, had deficiencies in border defense and inadequate detection mechanisms in Ghana and Nigeria. Children are also drawn from rural communities to urban areas in rural areas where insecurity and lack of education occur. The final destination of trafficked persons depends on their intention of trafficking. It is important to remember. However, Italy is the chosen target from Nigeria for most women victims. As such, people in North Africa were frequently stuck who could not enter Europe. Benin, Ghana, Nigeria, and Togo are the largest countries of origin in illegal child trafficking, smuggling children's domestic labor to the main urban centers in countries such as Congo, Equatorial Guinea, Ivory Coast, Gabon, and Nigeria, among others on the Nigerian coast.

Another notable feature is the cross-border connectivity as well as the porous nature. When European interests redrew national borders unilaterally in the late nineteenth century, ethnic groups were fragmented. This arbitrary existence has resulted in cross-border linkage (Eveslage, 2013). As a result, a background analysis of this linkage can be traced back to the development of ethnolinguistic relationships between peoples such as Nigeria and the Niger Republic in the north, as well as 
Nigeria and the Benin Republic in the south. This issue had called for a variety of influxes into many of the sub-countries. region's According to the above respondents from border officials, smugglers use a lack of proper protection, efficient paperwork, and identification systems, especially in Nigeria and Ghana, as an escape route. This is apparent in the fraudulent acquisition of visas or the falsification of documentation, as well as the cooperation of unscrupulous immigration officers. Furthermore, the Economic Community of West African States (ECOWAS) free movement of people encourages fast migration into other areas of West Africa; and the inadequate ability of these states, as well as the apparent unfavorable socioeconomic circumstances of these countries.

\subsection{Insecurity:}

The crisis in northeast Nigeria owes its origins broadly speaking to the insurgency of Boko Haram, a terrorist organization chargeable for assaults on nearby groups throughout Nigeria, Chad, Cameroon, and Niger. The sports of this terrorist organization and the counter-insurgency through the Nigerian nation prompted the more severe humanitarian disaster withinside the records of Nigeria. The precarious socio-financial situations of this place as a result of its touchy weather situations and forget through the crucial authorities are suspected to have created a fertile floor for Boko Haram to prosper. The strategic vicinity of the location occupied through Boko Haram's troops did now no longer most effective offer them with refuge far from national security forces, however additionally to be had manpower from the determined youths that struggled to make a living. Boko Haram recruits its individuals specifically amongst disaffected youths, unemployed excessive college and university graduates, and destitute children, broadly speaking from however now no longer restrained to northern Nigeria (Kamta, Azadi, \&Scheffran, 2020).

In order to examine the nature of the war economy in northeastern Nigeria, it is important to understand the impact of the conflict: an estimated 15 million people in northeastern Nigeria are affected by violence and military actions. According to reports, this situation has been particularly serious since 2014, resulting in approximately 20,000 deaths and 1.8 million displacements. This has led to poor economic development in the Northeast. The damage to the infrastructure is estimated at US\$9.2 billion, which in turn caused cumulative production losses of US $\$ 8.3$ billion. Although most of the displaced remain in the three conflictaffected states (Borno, Adamawa, and Yobe), the rest have moved to northern and central Nigeria. There are shelters for more than 170,000 people in neighboring countries (Avis, 2020).

The destruction of education and sanitation facilities, attacks on markets and farms, the closure of livestock markets, and restricted access to land have negatively affected livelihoods and the development of an entire generation. Driven by increasing humanitarian crises of food insecurity and increasing pressure on already overwhelmed basic social services (which exacerbated the pre-existing socio-economic inequality in the Northeast), the conflict still destroys social cohesion and interaction. Violence persists due to community, property, and land disputes and retaliation for conflict-related violence. The impact of the conflict on the six states in the region is mixed. Adamawa, Borno, and Yobe suffered severe physical damage and the displacement of displaced persons, destroying the local economy. The internally displaced persons in Bauchi, Gombe, and Taraba are overcrowded, which has placed a heavy economic burden on them. The conflict in the host country severely affected food production and agricultural productivity, especially in the worst-affected states of Borno, Yobe, and Adamawa. Population inequality and displacement prevent families from maintaining their usual livelihoods and hinder trade and markets. Limited food supplies and access to farms and markets in Borno, Yobe, and Adamawa have created local food crises related to severe food insecurity (Brechenmacher, 2019).

Commerce and trade were affected negatively with the aid of using lack of confidence thru disrupted exchange flows, will increase in transaction fees, dangers to formal region monetary sports, and outflow of investment because of uncertainty. Trade, especially in agriculture, has been impacted with the aid of using the war thru the destruction of establishments in addition to shipping routes. It has underscored extended transaction fees withinside the requisition of obligatory bills and tribute from manufacturers with the aid of using Boko Haram, increased shipping fees, and dwindled exchange levels. This has had an immediate effect on growing food fees withinside the location and beyond. Commercial sports were challenged with the aid of using lack of confidence thru uncertainty that has compelled Foreign Direct Investment (FDI) divestments from the location. There has additionally been high threat publicity to monetary offerings which have served to restrict get right of entry to customers and threat a retreat of two much fewer formal spaces.

\subsection{Loss of Socio-Cultural and Communal Value System}

Nigeria's norms and values are not human inventions or social products, but religious products. Their existence is due to the sanctions and requirements of God, gods or gods, and Nigerian values are an important part of our social and cultural system. ...The ignorance of religious education and Nigeria's norms and values have led to a decline in morality, which makes society safer. The pre-colonial life in Nigeria was largely influenced by religion because human beings were born as religious creatures. The belief that God, ancestors, and gods play an important role in maintaining social morality cannot disappear. However, indeed, modernity or civilization has greatly changed the beliefs and values of Nigerians. It is necessary to revive Nigeria's values, such as the sanctity of human life, social life, good interpersonal relationships, hospitality, religious beliefs, and money. Red and respect for officials and elders will bring sanity to the 
country. If you actively promote its moral standards and values, society will benefit a lot. Kidnapping, rubber weapons, murder, and property destruction have caused many Nigerians to lose property and lives. If both the public and private sectors violate the norms and values related to basic human rights, the people and the government will live in an atmosphere of instability and insecurity, which is not conducive to national change. A few words about the key concepts used in this research may be organized (Okobia, Okafor, \& Osajie, 2016).

The traditional belief structure of Nigerian society, much like most African cultures, has such delicate characteristics as collectivism, a devotion towards authority and culture, trueness, integrity, hard work, toleration, respect towards others (Clifford, 2009). The abhorrence of stealing and high regard for life are other distinguishing characteristics of Nigerian traditional culture. Stealing was seen as particularly disgraceful, and life was often greatly appreciated. The interference in Nigeria of other illegal immigrants progressively removed all these ideals that protected and made society safe and stable. In the so-called 'modernity and culture' new ideals have taken their position over the years. We have traded all our loving ideals and morality for the West.This was the result of mistrust between different ethnic groups and between the country's main faiths. Ethno-religious conflicts in Nigeria have been described as a key cause of instability. An ethnoreligious conflict has been described as a situation of lack of cordiality, reciprocal distrust and fear, and a propensity to a violent confrontation, characterizing the connection between members of one ethnic or religious community and another of the group in a multiethnic and multi-religious society. Frequent and recurrent racial and religious tensions. The nation is faced with a big security threat by the two prevalent faiths (Islam and Christianity). Ethno-religious disputes occur in all parts of Nigeria, as reported in Ibrahim and Igbuzor (2002). New and unusual ways of political understanding and identification have arisen frequently clustered around ethnoreligious identities. The demand for scarce capital, money, property, leadership, the local authorities, councils, market regulation, and Sharia amongst other trivial issues resulted in widespread murder and violence among groups in Nigeria (Achumba\&Akpor-roparo, 2013).

The Nigerians in the northeast region engaging in the drug trade and smuggling due to border porosity illicit migration. Heroin, opium, cocaine, and synthetic substances are widely trafficked. At the very dawn of independence, this drug threat became one of Nigeria's great security problems by finding cannabis farms in that region, arresting Nigerian cannabis smugglers outside Nigeria, and documenting psychological disturbances suspected of having to do with cannabis. However, in the early 1980s, after the suspected participation of military forces in the opium trade in Nigeria, the issue of drug trafficking became a significant one. Heroin and cocaine are a big cause of Nigeria. Nigerian pharmaceutical traffickers use vast quantities of small smugglers, each with a small amount of opium, often stuffed into condoms and then swept. Nigerian smugglers provide a big route for opium and cocaine to Europe and the United States: Ghana, the Ivory Coast, Senegal, and South Africa. The highest amounts of cocaine collected by commercial air flights are the origins of Nigeria and Senegal. The threat of drug trafficking in and outside the country needed many drogue legislation and policies to be enacted. In the world, the intimidating threat to safety is becoming prominent in drug addiction. As a result of open borders and poor safety at airports, drugs come into the world. $37 \%$ of Kano State's population were drug addicts and the state also has the largest number of persons detained for illegal drug trade according to official statistics from the National Drugs Law Enforcement Agency (NDLEA).

\section{CONCLUSION}

In conclusion, we should understand that borders are one of the most vital aspects of a state's national security. This is because states protect their national territory as among their qualities, though, border issues remain the citizen's integral part of life. Because of economic hardship, political instability, employment opportunities, citizens tend to leave their home countries to go and search for nearby and employment opportune countries. For these reasons, migrations and management of borders between Nigeria and her neighbouring countries seem to be a serious challenge, more especially if we look at the fact that there are intermarriages between the local communities at the border sides, the use of common language, which constitute easy communication and convincing methods towards authorities managing the borders among others.

Scholarly writings on international boundary politics have shown how states' geography, states' interdependence, and threats result in interstate conflict, disputes, and war though it has been further presented those interstate wars are more often facilitated by border politics. Boundary politics are those territorial claims over the demarcation of borders between two neighbouring states or their land areas trying to justifying the ownership of the boundary. The border disputes between Nigeria and Cameroon and their implication on national security took a series of dimensions in international relations. Both the two countries evolved through British colonial masters, though with French from other parts of Cameroon, the border situation left many ethnic groups and their territories partitioned to both sides of colonies. Border issues between the two countries began after each of them gained their political independence, and out of a quest for economic and agricultural development which is abundant in the Bakassi side, the two countries each tried to take over the location to be part of her territory.

\section{REFERENCES}

[1] Achumba, I. C., Ighomereho, O. S., \&Akpor-Robaro, M. O. M. (2013). Security challenges in Nigeria and the implications for business activities and sustainable development, Journal of economics and sustainable development, 4(2). 
[2] Adebakin, M. A., \& Raimi, L. (2012). National security challengesand sustainable economic development: Evidence from Nigeria. Journal of Studies in Social Sciences, 1(1).

[3] Adeola, G. L., \&Fayomi, O. O. (2012). The political and security implications of cross-border migration between Nigeria and her francophone neighbours. International Journal of social science tomorrow, 1(3), 1-9.

[4] Adepoju, A. (2005), Migration in West Africa, A Paper prepared for the Policy Analysis and Research Programme of the Global Commission on International Migration, Geneva.

[5] Adesola, F. (2008). National Security in Nigeria's Relations with its Neighbours. Ph.D. thesis, Department of International Relations, Obafemi Awolowo University, Ile Ife, Nigeria.

[6] Akinyemi, O. (2013). Globalization and Nigeria border security: Issues and challenges. Globalization, 11, 96-117.

[7] Avis, W. (2020). War Economy in North-East Nigeria.

[8] Awortu, B. E. (2015). Boko Haram insurgency and the underdevelopment of Nigeria. Research on Humanities and Social Sciences, 5(6), 213-220.

[9] Babatola, J. E. (2015). Challenges of Nigeria's Borders and Frontier Security. In Seminar paper.

[10] Bellany, I. (2005). Deaths among Iraqis due to the war 2003present day. The RUSI Journal, 150(1), 12-14.

[11] Brechenmacher, S. (2019). Stabilizing Northeast Nigeria After Boko Haram. Carnegie Endowment for International Peace.

[12] Chijioke U.S \& Chibuzor O.E (2013). Insecurity and National Economic Development, Implications for Nigeria's Vision 20: 2020. International Journal of Humanities and Development.

[13] Clifford, C. (2009). New Beginnings Retrieved from: www.cliffordchance.com/content/.../cliffordchance/.../new_beginn ing.

[14] Daniel G.H and Kwopman B. (2018) Nigerian Security Challenges and Sustainable, Development: A Critical Analysis of the Niger Delta Area. European Institute for Research.

[15] Eroukhmanoff, C. (2018). Securitization theory. E-International Relations Publishing.

[16] Ewetan O.O and Urhie E. (2014) Insecurity and Socio-economic Development in Nigeria Journal of Sustainable Development Studies.
[17] Ibrahim, J. and Igbuzor, O. (2002) "Memorandum submitted to the Presidential Committee on National Security in Nigeria."

[18] Ikome, F. N. (2012). Africa's international borders as potential sources of conflict and future threats to peace and security. Institute for Security Studies Papers, 2012(233), 16-16.

[19] International Organization for Migration, (2014). Chatham House, United Kingdom.

[20] Kamta, F. N., Azadi, H., \&Scheffran, J. (2020). The Root Causes of the Crisis in Northeast Nigeria: Historical, Socioeconomic and Environmental Dimensions. Mediterranean Journal of Social Sciences, 11(3), 95-95.

[21] Kathleen C. (2014). Boko Haram and Nigeria's Economy: Why the Poorest Suffer Most.

[22] Mabogunje Akin, (1972). Regional Mobility and Resource Development in West Africa McGill -Queen's University Press, Montreal, and London.

[23] Marenin, O. (2010). Challenges for integrated border management in the European Union. Geneva Centre for the Democratic Control of Armed Forces (DCAF).

[24] Mohammed, H. S. (2017). Nigeria's Border and Its Effect on the Economic and Security Development: A Case of Northern Borders in Nigeria. American Finance \& Banking Review, 1(1), 50-61.

[25] Okobia, F. N., Okafor, M. I., \&Osajie, J. N. (2016). Reactivating Nigerian norms and values through religious studies for national transformation. OGIRISI: A New Journal of African Studies, 12, 151-168.

[26] Okumu, W. (2011). Border management and security in Africa. Concordis Briefing, 4(4).

[27] Simon, O. E. (2011). Trans-Border Crime and its Socio-Economic Impact on Developing Economies. Journal of Sociology, Soc Anth, 2(3).

[28] World Bank (2007). Nigeria Poverty in the Midst of plenty. The Challenge of Growth without Development. A World Bank Poverty Assessment. Abuja: Will R.E. and Valter.

[29] World Food Summit (2003), Agriculture and Sustainable Development, Rome: FAO. 